\title{
A critique of the WHO TobReg's "Advisory Note" report entitled: "Waterpipe tobacco smoking: health effects, research needs and recommended actions by regulators"
} Kamal Chaouachi*

\author{
Address: Researcher in Socio-Anthropology and Tobaccology, Consultant in Tobacco Control, 62, avenue Victor Hugo; 92100 Boulogne \\ Billancourt, France \\ Email: Kamal Chaouachi* - kamcha@gmail.com \\ * Corresponding author
}

Published: 17 November 2006

Journal of Negative Results in BioMedicine 2006, 5:17 doi:10.1186/1477-575I-5-17

This article is available from: http://www.jnrbm.com/content/5///17

(c) 2006 Chaouachi; licensee BioMed Central Ltd.

This is an Open Access article distributed under the terms of the Creative Commons Attribution License (http://creativecommons.org/licenses/by/2.0), which permits unrestricted use, distribution, and reproduction in any medium, provided the original work is properly cited.
Received: 19 July 2006

Accepted: 17 November 2006

\begin{abstract}
Background and aim: The World Health Organisation Study Group on Tobacco Product Regulation (TobReg) has issued in 2005 an "Advisory Note" entitled: "Waterpipe Tobacco Smoking: Health Effects, Research Needs and Recommended Actions by Regulators". "Waterpipe" smoking is now considered a global public health threat and the corresponding artefact is actually known in the world under three main terms: hookah, narghile and shisha. This important report, the first ever prepared by WHO on the subject, poses two major problems. On one hand, its bibliographical references dismiss world chief relevant studies. On the other, it contains a certain number of errors of many orders: biomedical, sociological, anthropological and historical. The purpose of the present study is to highlight, one by one, where these weaknesses and errors lie and show how this official report can be considerably improved.
\end{abstract}

Results: We realise that widely advertised early anthropological studies were not taken into consideration whereas they shed a substantial light on this peculiar form of smoking and help understanding its high complexity. As for concrete errors to be found in this report, they deal with the chemistry of smoke, health-related effects, smoking patterns, description and history of the artefact and its use, gender and underage use aspects, prevention and research needs in this field.

Conclusion: The scientific credibility of an international expert report may be at stake if its recommendations do not rely on sound objective research findings and a comprehensive review of the existing literature. The critical comments in this study will certainly help improve the present WHO report.

\section{Background}

The World Health Organisation Study Group on Tobacco Product Regulation (TobReg) has issued in 2005 an "Advisory Note" entitled: "Waterpipe Tobacco Smoking: Health Effects, Research Needs and Recommended Actions by Regulators" [1](see Figure 1). This report was prepared "in response to requests made by those Member States whose populations are exposed to this form of tobacco use" and was adopted at a meeting in Rio de Janeiro on 7-9 June 2005. This document is mainly based on a background paper drafted by Dr Thomas Eissenberg (USA) and Dr Shihadeh (Lebanon), actually commissioned for this purpose by Dr 
Yumiko Mochizuki, Director of the WHO Tobacco Free Initiative, with the collaboration of Dr Maziak (Syria), Dr Israel and Dr Loffredo (USA) and Dr Mohamed (Egypt)[1]. Research led at the SCTS (Syrian Center for Tobacco Studies) formed an essential part of the report.

Such an official publication, which has remained uncommented so far, actually poses two major problems. The first one relates to its bibliographical references which dismiss world chief relevant studies, both in the biomedical and social sciences field. The case of the existing anthropological studies is particularly striking given the recognised importance of the socio-cultural dimension of this peculiar form of smoking. Indeed, the narghile practice is deeply rooted in a complex network of closely interrelated social, cultural and health issues in a given human context. The second problem deals with the multiple errors contained in the report. These are of many orders: biomedical, sociological, anthropological and historical.

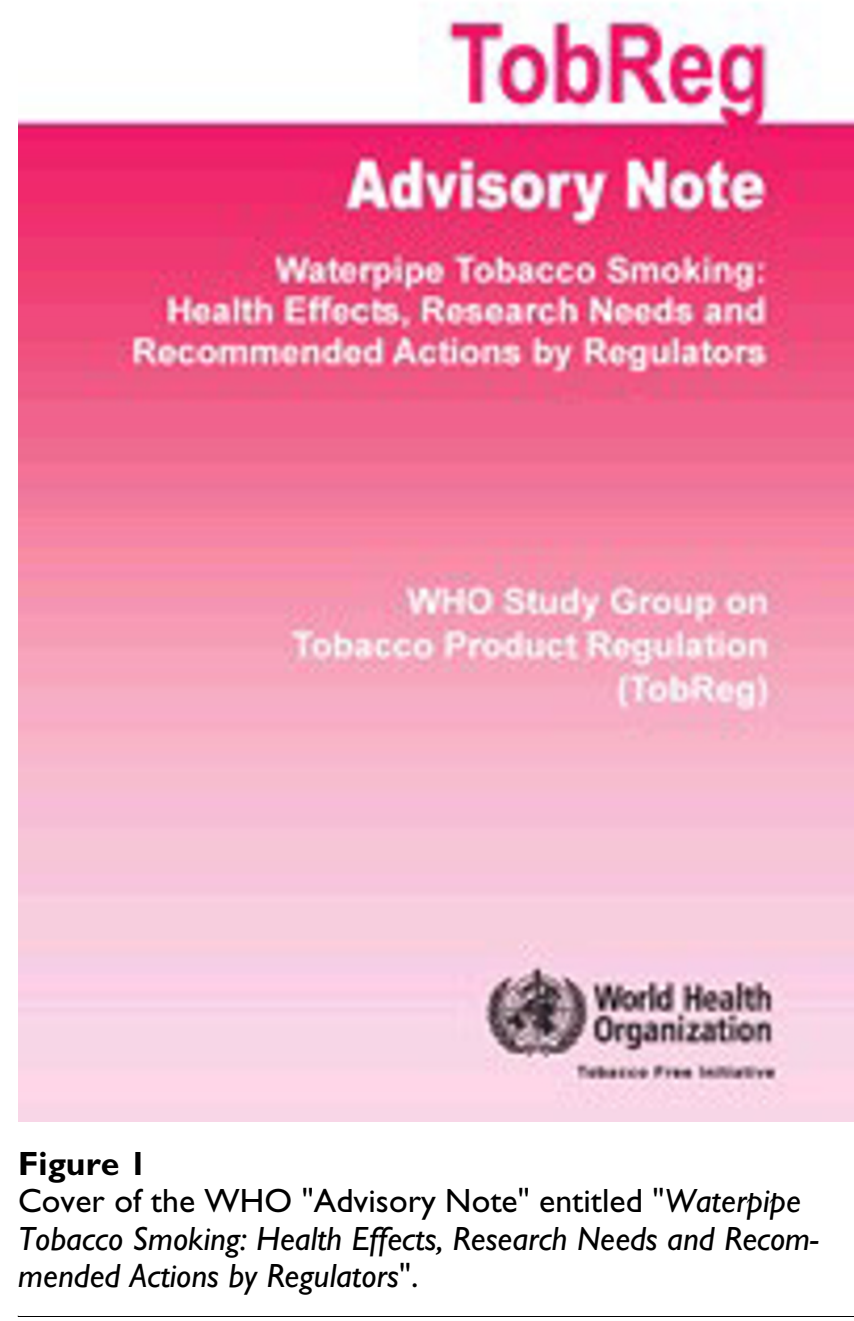

Consequently, the aim of the present article is to highlight, one by one, where these weaknesses and errors lie and show how the WHO report can be considerably improved. We certainly share the health concerns stemming from the growing use of hookah (narghile, shisha, water-pipe) in the world. However, the scientific credibility of an international expert report may be at stake if recommendations do not rely on sound objective research findings.

In this study, we recall the importance and relevancy of the missing and glossed over references and critically review some of those cited by the authors. As for the errors, they are analysed under relevant subsections in the Results and Discussion section below.

\section{Results and discussion Origins}

It is said (page 1) that, according to Chattopadhyay, "waterpipes have been used to smoke tobacco and other substances by the indigenous peoples of Africa and Asia for at least four centuries" [2]. The quotation is not accurate because this author does not mention, at any point, any of these facts in his article. Besides, evidence concerning the Indian origin of the hookah is weak. As a matter of fact, the most ancient traces were found in Southern or Eastern Africa [3]. For instance, bowls of water-pipes were dug out in 1971 by J.C. Dombrowski in the Lalibela cave (Ethiopia). C14 datation situated their use around years $1320+/$ - $80[3,4]$. As for the large scale emergence of the narghile in society, either for an individual or collective use, historical accounts show that it was simultaneous with the appearance of the public coffee-houses and the adoption of tobacco in the Middle East region: near the end of the $16^{\text {th }}$ century and the beginning of the $17^{\text {th }}$ century (ibid.)(see Figure 2). For the authors of the report, the myth of the hookah as a safer way of smoking is as old as its invention in India. However, there is no point in insisting on the necessity of this Indian origin because it is also a myth itself.

\section{Tar yields}

According to the report (page 1), "Marketing tools associated with waterpipes and waterpipe tobacco may reinforce this unsubstantiated belief. For example, the label of a popular waterpipe tobacco brand sold in South-West Asia and North America states '0.5 nicotine and $0 \%$ tar". An investigation was actually carried on with a similar product in France $[3,5,6]$ and we had the possibility to clarify this point by stressing the importance of parameters such as the puffing frequency, volume and others (id.). These above figures were actually obtained with light smoking parameters similar to those used for cigarette smoking. Consequently, they do not reflect a less realistic view of human hookah smoking than others where the severe conditions 


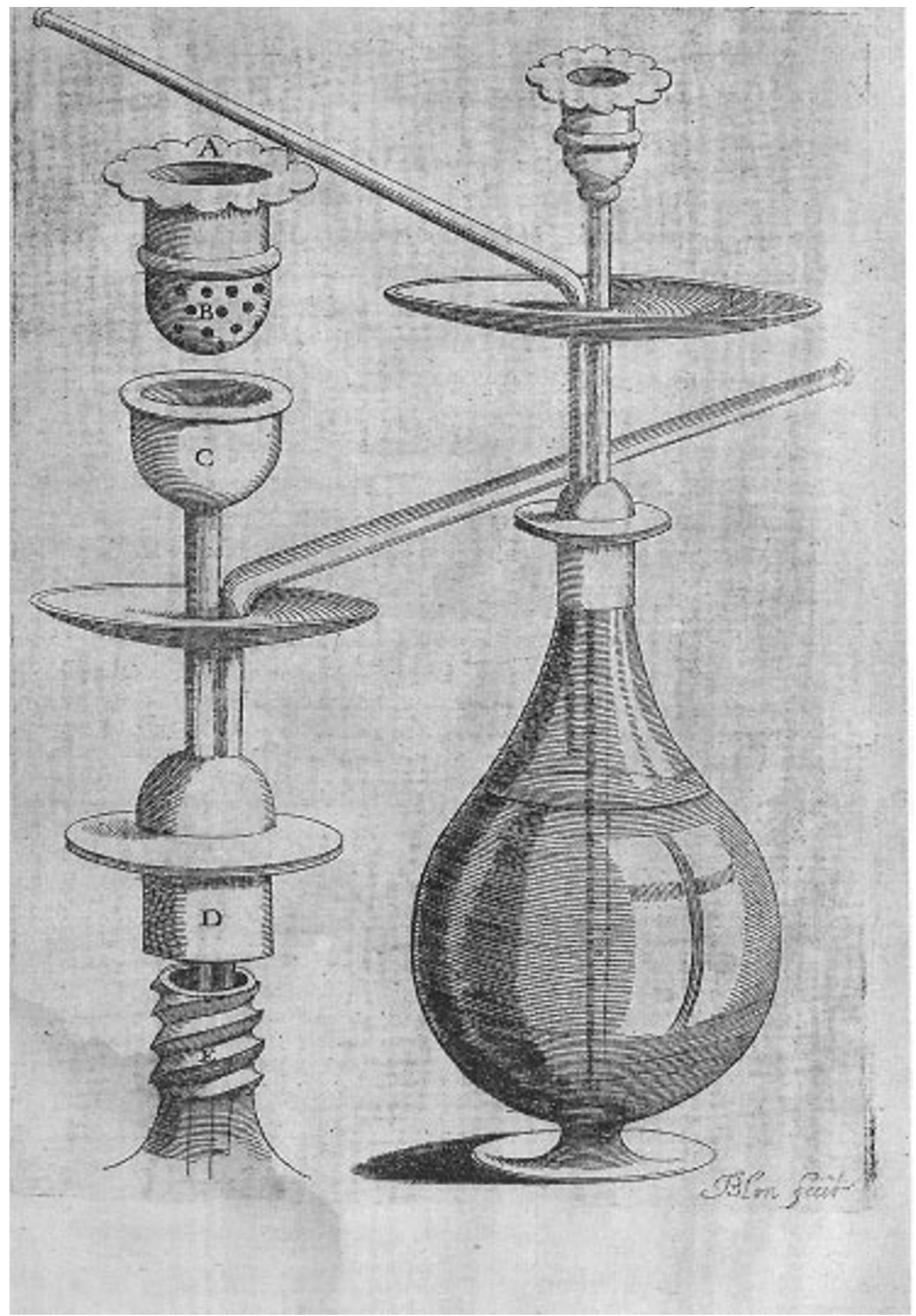

Figure 2

A Persian qalyân (1622). In Tabacologia, Johann Neander's masterpiece (1622). Drawing by Blon. 
imposed to a hookah smoking machine allowed the production, among others, of huge quantities of tar $[7,8]$.

The quantity of tar obviously depends on the inhalation frequency. For instance two important, not cited, studies dealt with tumbâk $[9,10]$ and used different puffing parameters than the recent one that relied on tobamel (tobacco-molasses smoking mixture, called "mu'essel" in Arabic)[8]. The discrepancies in results are striking: the two former found a reduction by c. 50\% of the tar (smoke compared with that produced by a narghile with no water inside) while the latter succeeded in producing impressive amounts of it: $802 \mathrm{mg}$ for a one-hour session. The explanation lies in the fact that, in the last case, the laboratory model completely differed from actual human hookah smoking. Only a small quantity of the smoking mixture was used: $10 \mathrm{~g}$ instead of the average $20 \mathrm{~g}$ according to an important work by Hadidi [11]. The coal, of the quicklighting type, of unknown chemical composition, was kept in the same place over the tobacco-molasses mixture during the whole session, that is, almost one hour, versus $45 \mathrm{~min}$ [11]. This is contrary to the normal practice that involves moving it around in order to avoid "charring" the product. Puffs of a great volume $(530 \mathrm{ml})$ were drawn periodically and at a fast pace: every $17 \mathrm{~s}$ vs. $30 \mathrm{~s}$ [11]. In these conditions, 171 puffs were taken, vs. 90 [11]. These parameters were actually set according to a calculated average of figures collected through a smoking topography in a café. Strangely enough, the corresponding data were analysed, in their great majority, for the first 30 minutes of smoking only. Moreover, it is known that beyond that period, the interval between puffs tends to be much longer though remaining irregular. Over a whole session, the smoking variables have, randomly and in a drastic way, many ups and downs. Consequently, from a methodological standpoint, the use of an average figure over such a long span of time, particularly for puff frequency, is a serious methodological distortion. Indeed, specialists advise against the use of smoking machines in the field of cigarette, where, however, the smoking session is extremely short in comparison with the hookah: "Kozlowski likened the FTC test to trying to measure caloric intake by inventing an eating machine. A better method he said, might be to study changes in people after eating. Similarly, studying the effects of cigarettes in actual people may be better than using a machine-based system. "In other words, cut out the machine smoker as the middleman, " he said" [12].

Moreover, there are also other important parameters that could change the amount and nature of the substances absorbed by the smoker: aspiration speed, pressure, water solubility of certain substances, volume of bowl, amount and temperature of water, added substances, length of the aspiration hose and others... What renders the tar dangerous is not its quantity but its quality and above all its tem- perature. In these conditions, the scientific truth is certainly to be found between these two extreme figures: neither " $0 \%$ tar" as claimed on commercial tobamel packages nor " $802 \mathrm{mg}$ " artificially produced in unrealistic conditions in a laboratory.

As for nicotine, despite the above mentioned strain parameters, the nicotine yield, compared to that found in a single cigarette, is far from scaring the "hookah addicts" or even suggesting an explanation to their behaviour. Consequently, this issue shows that what is now needed is simulating, in a laboratory, the reality of human hookah smoking. If we want to be credible in our prevention efforts, artificial smoking, which generates great quantities of $\operatorname{tar}[7,8]$, should be avoided if we want to avoid confusion.

\section{Heating and burning}

The report states (page 2) that "the tobacco that is placed into the head is very moist (and often sweetened and flavoured): it does not burn in a self-sustaining manner". This sentence is confusing. First, one should talk of diverse smoking concoctions or mixtures. Only one type of tobacco, tumbâk (which is raw tobacco), is "very" moist(ened) because, before it is packed inside the bowl, it is soaked in water then squeezed to remove most of its water. The other one, referred to as "sweetened and flavoured", is differently processed. It contains glycerol. Besides, in the case of the "flavoured tobacco", it is definitely wrong to say that the mixture is burnt. It is simply heated and this is a crucial point [13]. Evidence for this is provided by the actual working temperatures that can be measured during the process. They are below or around $100^{\circ} \mathrm{C}$, a figure very different from that that can be measured at the tip of a cigarette $\left(850-900^{\circ} \mathrm{C}\right)$. In these conditions, the heat range allows chemical reactions of the Maillard type between the aldehyde functions of sugars - especially in the molasses element- and nitrogenous compounds, particularly ammonia $(\mathrm{NH} 4 \mathrm{OH})$ used by tobacco manufacturers to produce various aromatic compounds [3,14]. Moreover, as far as tar is concerned, all specialists know that what makes the latter hazardous and carcinogenous is not its quantities but it qualities. On one hand, these qualities depend to a great extent on the temperature at which tar is produced. On the other, knowing the crude amount of tar is useless, because its harmful components, i.e. nitrosamines, polycyclic aromatic hydrocarbons, represent a very variable and, in any case, small percentage of the total weight, which therefore is in no way a valuable index of its hazards. This is true for cigarette smoke, so that one should stop printing on cigarette packs the smoking machine tar yield, which gives the smoker a fallacious information about the real danger. This is even more true for narghile smoking, which is much more variable. Once again, we can see that hookah smoking is very peculiar in 
this respect. In these conditions, even second-hand smoke (pages 4 and 5 of the report) is completely different from that produced by cigarettes [15].

\section{Children}

We are informed (page 4) that "in South-West Asia and North Africa, it is not uncommon for children to smoke with their parents", citing the author of a so-called "dispatch" paper where we can read that: "It is socially acceptable for a father to offer his teenage children a puff of the nargile, in a way similar to a Frenchman offering a taste of wine to his sons and daughters" [16]. Despite the fact that this remark is quite personal and anecdotal, this does not mean at all that children "smoke with their parents", which is a totally unsupported statement in contradiction with all available anthropological data that rather describe narghile initiation as a kind of "rite of passage" [3,17].

More, recent epidemiological figures in Syria, an Arab country, are quite clear in this respect [18]: "Age of initiation differed according to method of smoking and gender. On average, men initiated use of cigarettes at age 17.9 (5.3) years and waterpipe at 25.5 (9.1) years, while women initiated use of cigarettes at 22.5 (8.4) years and waterpipe at 28.9 (9.9) years ( $p, 0.05$ for all gender and smoking method comparisons by test").

\section{Women}

In the same vein, we can read (page 4) that "in some countries in which cigarette smoking is concentrated among men, waterpipe smoking appears more evenly distributed between both sexes". This may be true in some countries but wrong in others. For instance, in Tunisia and Libya, cigarette smoking is still a male domain but "water-pipe" also. In these conditions, generalisation should be avoided because there is no "rule" in this field and this issue needs further comparativist anthropological research that already began for a decade now [15,19](see Figure 3).

\section{New charcoal}

The report states (page 5, $5^{\text {th }}$ conclusion) that "commonly used heat sources that are applied to burn the tobacco, such as wood cylinders or charcoal, are likely to increase the health risks because when such fuels are combusted they produce their own toxicants, including high levels of carbon monoxide, metals and cancer-causing chemicals". These potential inherent listed hazards linked to the use of the new quick-lighting commercial charcoal are wrongly attributed to the two cited references $[7,8]$. As far as carbon monoxide is concerned, the above mentioned studies relied only on this new charcoal and neither a comparison with natural charcoal nor an analysis of the composition of the former was carried on. There is only one study in the world which shows that a commercial charcoal yields higher levels of this gas than the natural one [20].
Concerning heavy metals, the new quick-lighting charcoal might be a source but also the tobacco itself, the aluminium foil an even the metal coating (particularly of the bowl). Therefore, as there is no study to date about the composition and health effects of this new heating source, researchers are highly encouraged to set about clarifying this issue $[3,5,6,13,21]$.

In any case, and if we only take two striking figures, that of the scaring yields for lead and carbon monoxide, 6870 ng and $143 \mathrm{mg}$ respectively $[7,8]$, they do not reflect at all the reality of hookah smoking. For instance, the results for the lead levels are not in agreement with a previous study by Salem concluding that the content of this metal was significantly higher in cigarette than in water pipe [22]. Other data from unpublished studies show that arsenic was not even detected. This is because the hookah smoking machine that was used $[7,8]$ was set with blown up "average" parameters supposed to reflect figures varying, in fact, in a dramatic way and over a very long period of time (one hour). This is a distorted model of actual human hookah smoking behaviour [12].

\section{Harm reduction}

In this field (page $5,8^{\text {th }}$ conclusion), there would be "no proof that any device or accessory can make waterpipe smoking safer". For many reasons, there is no proof. For instance, and contrary to a widespread idea among tobacco control activists, the hookah market is still in the hands of "traditional" segments of the economy, particularly located in the so-called South. The producers of these devices do not possess the research facilities of an international company like RJ Reynolds, whose scientists publish their studies in international biomedical journals. For instance, there is a certain amount of literature about the Eclipse cigarette, based on the principle of narghile smoking because it heats tobacco instead of burning it. However, harm reduction techniques have already been put forward by the authors of high quality studies in the field of research on hookah smoking. For instance, Shafagoj in Jordan suggests to "motivatemanufacturers to produce HB [hubble-bubble, i.e. hookah] filters to be inserted to the mouthpiece. In addition, $\mathrm{pH}$, resins or other modifications can be made to the HB water to improve its filter properties." [23]. In Arabia, Zahran early mentioned the existence of a device that obviously reduces, not to say inhibits, the production of carbon monoxide: an electric resistance used instead of the charcoal [24].

\section{Infections}

The report states (page 5, $9^{\text {th }}$ conclusion) that "sharing $a$ waterpipe mouthpiece poses a serious risk of transmission of communicable diseases, including tuberculosis and hepatitis". This statement is wrongly attributed to researchers [25] who are not the authors of studies on such risks. In the 


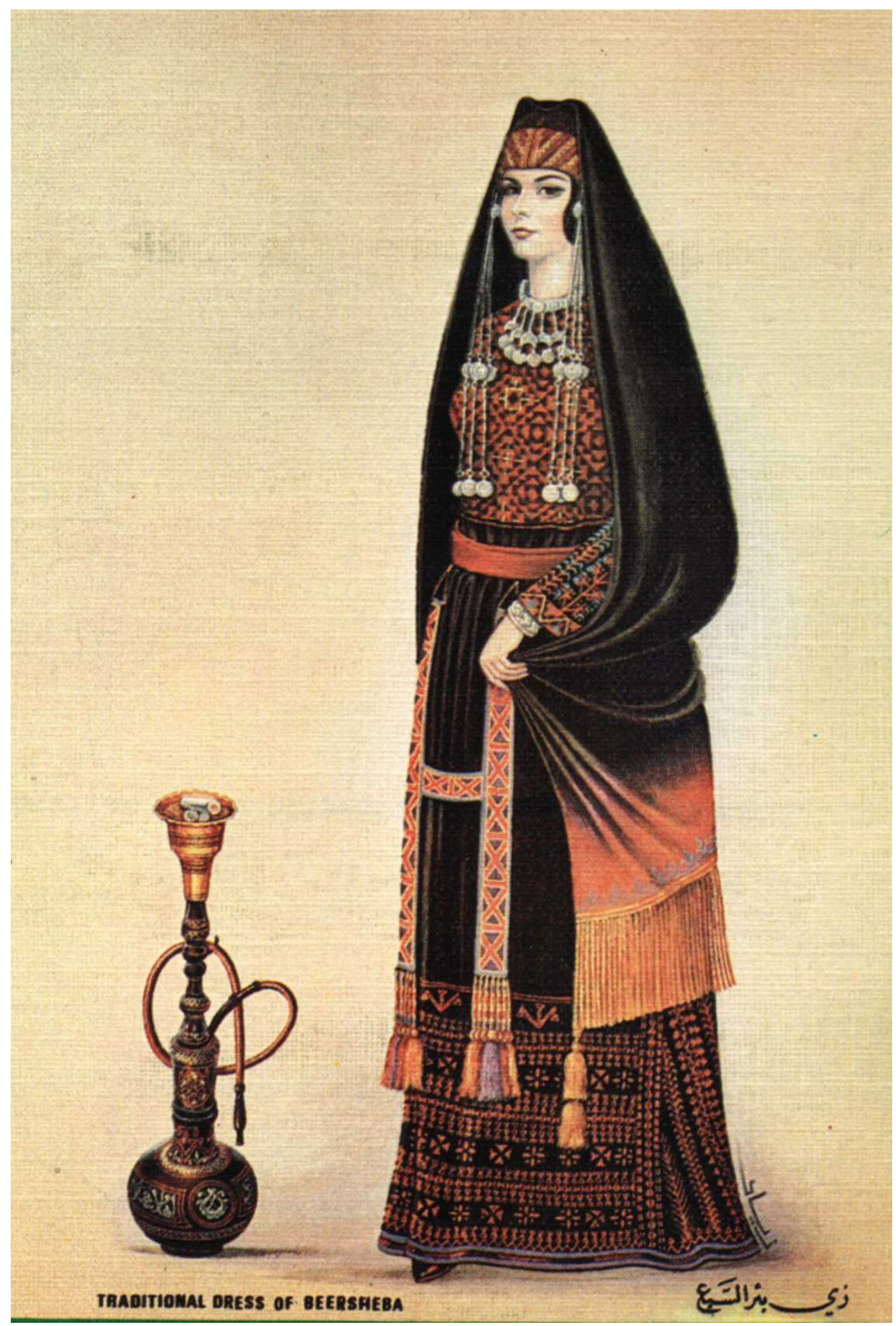

Figure 3

Traditional Palestinian Woman and Narghile. 
case of hepatitis, these studies were carried on by Habib et al. [26] and Medhat et al. [27]. As for tuberculosis, they were carried on, recently, by Munckhof et al. [28] and long before by Salem et al. [29]. Besides, the risk is not so "serious". If it had been so, the world would have witnessed corresponding epidemics over the last centuries. This did not happen. Finally, we note that plastic aseptic disposable personal nozzles are always served to patrons in the "hookah lounges" or during the fashionable home "hookah parties". Generally speaking, the risks are not clearly established because of a non-rigorous methodology (simultaneous use of other products [e.g. qât, cigarettes, bidis, etc], strongly neglected hygiene, current profile and remote and recent career of smokers not specified, etc.) $[13,21]$.

\section{Scenario for the epidemic}

We read (paragraph 10, page 5) that "waterpipe tobacco is often sweetened and flavoured, making it very appealing; the sweet smell and taste of the smoke may explain why some people, particularly young people who otherwise would not use tobacco, begin to use waterpipes". This quotation refers to a study that actually proposed a wrong "scenario" for the recent development of shisha use in Syria [30]. According to it, the Arab information satellite television channels would be greatly responsible for the development of the hookah craze. This argument is not consistent at all and the complex answer was treated in a key document [3]. The main reason is that the old Egyptian movies, that all television watchers of the Arab world remember quite well, were already heavily featuring narghile smokers long before the recent hookah epidemic and the emergence of satellite-powered TV channels. Moreover, it is also in contradiction with a paper cited as a key reference in the report and revealing: "Old Egyptian films showed groups of men sipping mint tea or strong coffee in cafés and smoking nargile for many hours" [16]. Unfortunately, this kind of quick analysis of a complex anthropological situation has led researchers of the very teams cited in this report to wade in a similar way [31].

\section{"Nicotine addiction"}

We deem it not necessary to insist too much on the biochemical and health dimensions provided that the methodological conditions are respected in order to avoid the too frequent bias. Two critical reviews in French and Italian, among others, were published on these very aspects $[3,5,6,13,21]$.

We also hope that in the coming future the nicotine addiction dogma will be sidestepped when tackling the dependence aspects. On one hand, it is not appropriate in the field of hookah smoking and the results of a study carried on by one of the very teams mentioned in this report, are quite clear: about 3/4 of the interviewees declared narghile use was easy to quit [32]. On the other, as far as dependence is concerned, there is a serious debate over the central role of nicotine in the dependence process $[33,34]$. Indeed, we are convinced that the future findings of the growing research on narghile will help reconsider the tobacco dependence issue in general and cigarette dependence in particular. People do not necessarily smoke the hookah for nicotine and another evidence for this is that the "hookah lounges" already offer herbal fruit-flavoured tobacco-free smoking mixtures to their patrons. The importance of flavours (only in the case of tobamel) would make this dependence very similar to that induced by coffee. Not only nicotine but MonoAmine Oxidase Inhibitors (MAOI), other minor low-dose potentially dependence-inducing alkaloids, ligands of opioid receptors, and other substances, might play a certain role in the dependence process [34].

\section{Chief studies}

Globally, we may wonder why controversial studies $[7,8,35,36]$ are cited in this report while other early and useful studies led by Hoffman [9], Rakower [10] and Salem $[22,29]$ are not. This is all the more regretful that the latter relied on traditional settings and the corresponding experiments were based on the use of the natural charcoal, not the new self-lighting one which likely causes, among others, an overproduction of carbon monoxide [20]. Indeed, what is interesting for the sake of scientific comparisons, is that one basic difference between the traditional four-century old social use of the hookah and the contemporaneous one is the nature of the heating source.

\section{Prevention}

Prevention is the most important and pressing issue and no suggested action (page 7) is given in this report whereas a public health catastrophe is looming and so many ideas could immediately be put forward to avoid it and reduce the harm caused by this new widespread form of smoking $[3,5,6,13,21,37]$.

\section{State of research}

The report states (page 6) that "there is surprisingly little research addressing tobacco smoking using a waterpipe, especially given that there are many millions of current waterpipe smokers and that waterpipe use is spreading across the globe". It is true that very little research has been devoted to the subject. Therefore to perform an exhaustive bibliography was not a superhuman task, and the WHO report should have done it. We personally regret that the authors did not even mention the deep and early health oriented anthropological research that we carried on in this field, which contains many ideas for the desired development of prevention and cessation strategies" $[3,5,6,13,21]$. These documents have been widely advertised, over the years 2000- 
2005, among the international community of tobacco control researchers and activists, particularly through the Globalink network. English abstracts, translations and comments of their findings were disseminated on a large scale.

\section{Drugs}

One can also read that there would be research needs for "the relationship between waterpipe smoking and the use of other drugs, including marijuana" (page 6). We will point out that a 262 page scientific book, entirely dedicated to this topic, was published as early as 1997 [38].

\section{Conclusion}

We hope these comments will be useful for the future reports which, we insist, should be clear and objective, if we want them to be accepted, as far as their recommendations are concerned, by health practitioners, prevention activists, researchers and the one-day or regular smokers themselves all over the world. Methodology needs substantial improvement. The World Health Organisation Study Group on Tobacco Product Regulation itself, responsible for the publication of this very report actually concluded in a meeting: "The International Organization for Standardization (ISO) machine-based cigarette test for determining the tar, nicotine, and carbon monoxide content of cigarettes should be banned and replaced" [12]. What is true for a 5 minute cigarette smoking session is even much more true for hookah smoking session which is 10 times longer and where the puffing variables extremely deviate from an arbitrary "average" figure. In these conditions, the use of a hookah smoking machine $[7,8]$ should be discontinued because it has led to a great deal of confusion, particularly reflected in the first report on "waterpipe smoking" ever published by WHO [1]. The $12^{\text {th }}$ core principle set out in another TobReg important report is: "Regardless of the funding mechanism adopted, it should ensure that the independence and integrity of research and testing operations are not compromised or inappropriately influenced " [39]. The same document insists that the output of research and testing laboratories be "credible and consistent with the most rigorous of international standards" (p.7, ibid.).

We invite our colleagues, particularly those working in the epidemiological field, to amend the design of their questionnaires and include one or several items related to the past and present career (ex-smoker [with quantification, detailed mention of dates an products], switching-smoker from cigarette to narghile, exclusive smoker, etc.) of the volunteers analysed in their studies $[5,21,37]$. This point is of utmost importance because it may render useless the corresponding results as this happened with most of the previous studies. In view of the quick development of hookah use in the world, we will definitely spare time and other resources for the benefit of the world human health.
On one hand, the strong socio-anthropological background of fashionable hookah smoking in a global world shows that the underlying social context bears similarities but also great differences with cigarette smoking [41]. On the other, it confirms that "public health is a social issue" as recently and relevantly emphasised by Dr Lee, Directorgeneral of the World Health Organisation [42].

\section{Methods}

The present work is based on a critical and thorough review of the WHO report. The findings of the studies cited by the authors are compared with the results of those not cited in that document, both in the biomedical and social sciences fields. We realised that the errors concretely deal with the following themes: the chemistry of smoke, health-related effects, smoking patterns, description and history of the artefact and its use, gender and underage use aspects, prevention and research needs in this field. Their corresponding analysis and comments are combined as far as possible and reported as subsections in the Results and Discussion section, namely: Origins; Tar yields; Heating and burning; Children; Women; New charcoal; Harm reduction; Infections; Scenario for the Epidemic; "Nicotine addiction"; Chief studies; Prevention; State of research; Drugs.

\section{Competing interests}

The author(s) declare that they have no competing interests.

\section{Acknowledgements}

The WHO (World Health Organisation) TobReg's "Advisory Note" report entitled "Waterpipe tobacco smoking: health effects, research needs and recommended actions by regulators" was published by the Tobacco Free Initiative in 2005.

TobReg is the WHO study group on Tobacco product Regulation. Its distinguished members are: Erik DYBING (Norway; Chairman); David L. ASHLEY (USA); David BURNS (USA); Mirjana DJORDJEVIC (USA); Nigel GRAY (France); S. Katherine HAMMOND (USA); Jack HENNINGFIELD (USA); Martin JARVIS (UK); K. Srinath REDDY (India); Channing ROBERTSON (USA); Ghazi ZAATARI (Lebanon).

\section{References}

I. World Health Organization (Tobacco Free Initiative): Advisory Note. Waterpipe Tobacco Smoking: Health Effects, Research Needs and Recommended Actions by Regulators 2005 [http://www.who.int/tobacco/ global interaction/tobreg/en/]. (retrieved I5 Dec. 2005)

2. Chattopadhyay A: Emperor Akbar as a Healer and his Eminent Physicians. Bull Indian Inst Hist Med Hyderabad 2000, 30(2): I 5 I - 157.

3. Chaouachi K: Le narguilé: analyse socio-anthropologique. Culture, convivialité, histoire et tabacologie d'un mode d'usage populaire du tabac. In Transdisciplinary doctoral thesis, Université Paris X (France) ANRT (Lille); 2000. [Eng.: Narghile (hookah): a Socio-Anthropological Analysis. Culture, Conviviality, History and Tobaccology of a Popular Tobacco Use Mode]. 420 pages

4. Van Der Merwe NJ: Cannabis Smoking in 13th-14th Century Ethiopia: Chemical Evidence. In World Anthropology: Cannabis and Culture Vera Rubin: Mouton Publ. (The Hague); 1975:77-80.

5. Chaouachi K: Presentazione del narghilè e del suo uso. Guida critica della letteratura scientifica sul narghilè (shisha, 
hookah, waterpipe). Dalle origini ai giorni nostri : necessità di un approccio interdisciplinare socio-antropologico, medico e farmacologico. Tabaccologia 2005, I:39-47 [http:// www.tabaccologia.org/archivio.htm]. [Eng. A critical review of scientific literature on narghile (Shisha, Hookah, Waterpipe) from its origins to date: the need for a comprehensive socio-anthropological, medical and pharmacological approach]

6. Chaouachi K: Narghile: aspetti chimici e farmacofisiologici. \begin{tabular}{l} 
Tabaccologia 2005, 3:27-33 [http://www.tabaccologia.org/ \\
\hline
\end{tabular} archivio.htm]. [Eng.: Biochemical and Pharmacological Aspects of Narghile]

7. Shihadeh A: Investigation of mainstream smoke aerosol of the argileh water pipe. Food and Chemical Toxicology 2003, 4 I: I 43-I 52.

8. Shihadeh A, Saleh R: Food and Chemical Toxicology : Polycyclic aromatic hydrocarbons, carbon monoxide, "tar", and nicotine in the mainstream smoke aerosol of the narghile water pipe. Food and Chemical Toxicology 2005, 43(5):655-661.

9. Hoffman D, Rathkamp G, Wynder EL: Comparison of the yields of several selected components in the smoke from different tobacco products. Journal of the National Cancer Institute 1963, 3I:627-635.

10. Rakower J, Fatal B: Study of Narghile Smoking in Relation to Cancer of the Lung. Br J Cancer 1962, 16:1-6.

II. Hadidi KA, Mohammed FI: Nicotine content in tobacco used in hubble-bubble smoking. Saudi Medical Journal 2004, 25(7):9|2-9|7.

12. Zielinski S: Smoking Machine Test Inadequate and Confusing, But No Replacement a Decade Later. Journal of the National Cancer Institute 97(I): I0-I. 2005 (Jan 5)

13. Chaouachi K: Patologie associate all'uso del narghile. [Eng. Narghile-Related Diseases]. Tabaccologia 2006, I:27-34 [http:// www.tabaccologia.org/archivio.htm].

14. Saint-Jalm Y: Technologie du tabac [Eng. Tobacco Technology]. In Séminaire du DIU de Tabacologie (Dir. Robert Molimard) Faculté de Médecine Paris-Sud, CHU Kremlin-Bicêtre (France); 2004.

15. Chaouachi K: E-Letter to the Editor: Measuring Real Exposure to Narghile (Hookah, Shisha) Smoke and Other Concerns Related to Public Health. European Journal of Public Health [http:l leurpub.oxfordjournals.org/cgi/eletters/ckl043vl\#18]. 2006 (Jul 2), 4 pages

16. Kandela P: Nargile smoking keeps Arabs in Wonderland. The Lancet 2000, 356(9236): I 175 .

17. Chaouachi K: Le narguilé au Yémen [Eng. Narghile Smoking in Yemen]. In D'un itinéraire à l'autre Edited by: Naim S. Paris: Maisonneuve et Larose; $2001: 130-147$.

18. Ward KD, Eissenberg T, Rastam S, Asfar T, Mzayek F, Fouad MF, Hammal F, Mock J, Maziak W: The tobacco epidemic in Syria. Tobacco Control 2006, I5:24-29 [http://tc.bmijournals.com/cgi/elet ters/I5/suppl I/i24].

19. Chaouachi K: Culture matérielle et orientalisme. L'exemple d'une recherche socio-anthropologique sur le narguilé. Arabica (Koninklijke Brill NV, Leiden) 2006, LIII(2177-209 [http:/l www.ingentaconnect.com/content/brill/arab/2006/00000053/ 00000002/art00003]. [Eng.: Material Culture and Orientalism. The Example of a Socio-Anthropological Research on Narghile]

20. Sajid KM, Akther M, Malik GQ: Carbon monoxide fractions in cigarette and hookah. J Pak Med Assoc 1993, 43(9): $179-182$.

21. Chaouachi K: Shisha, hookah. Le narguilé au XXle siècle. Bref état des connaissances scientifiques. Le Courrier des Addictions 2004, 6(4):150-152. [Eng.: Narghile, Hookah in the 2 Ist Century: An Overview of the Scientific Knowledge]

22. Salem ES, Mesrega SM, Shallouf MA, Nosir MI: Determination of lead levels in cigarette and goza smoking components with a special reference to its blood values in human smokers. In The Egyptian journal of chest diseases and tuberculosis Volume 37. Issue 2 Edited by: Radwan GN, Mohamed MK, El-Setouhy M. Israel E: Review on waterpipe smoking; 1990. J. Egypt. Soc. Parasitol 2003 (Dec), 33, Suppl 3 |05I-107|

23. Shafagoj YA, Mohammed FI, Hadidi KA: Hubble-Bubble (Water Pipe) Smoking: Levels of Nicotine and Cotinine in Plasma, Saliva and Urine. Int J Clin Pharmacol Ther 2002, 40(6):249-255.

24. Zahran FM, Ardawi MSM, Al-Fayez SF: Carboxyhaemoglobin concentrations in smokers of sheesha and cigarettes in Saudia Arabia. BMJ 1985, 291:1768-1770.
25. Knishkowy B, Amitai Y: Water-Pipe (Narghile) Smoking: An Emerging Health Risk Behavior. Pediatrics 2005, II6(I):el13-119.

26. Habib M, Mohamed MK, Abdel-Aziz F, Magder LS, Abdel-Hamid M, Gamil F, Madkour S, Mikhail NN, Anwar W, Strickland GT, Fix AD, Sallam I: Hepatitis $C$ virus infection in a community in the Nile Delta: risk factors for seropositivity. Hepatology 200I, 33(I):248-253.

27. Medhat A, Shehata M, Magder LS, Mikhail N, Abdel-Baki L, Nafeh M, Abdel-Hamid M, Strickland GT, Fix AD: Hepatitis $C$ in a community in Upper Egypt: risk factors for infection. Am J Trop Med Hyg 2002, 66(5):633-638.

28. Munckhof WJ, Konstantinos A, Wamsley M, Mortlock M, Gilpin C: A cluster of tuberculosis associated with use of a marijuana water pipe. Int J Tuberc Lung Dis 2003, 7(9):860-865.

29. Salem ES, Abdel-Hakim M, Hanafi A: Goza versus cigarette smoking among patients with pulmonary disease. The Egyptian journal of chest diseases and tuberculosis 1973, I6(2): 121-140.

30. Rastam S, Ward KD, Eissenberg T, Maziak W: Estimating the beginning of the waterpipe epidemic in Syria. BMC Public Health 2004, 4:32.

31. Chaouachi K: Letter to the Editor: Some Misconceptions in a Good Alert Paper. Tobacco Control [http://tc.bmijournals.com/cgi/ eletters//4/6/363-a\#479]. 2006 (I8 Jan)

32. Ward KD, Hammal F, Vander Weg MW, Eissenberg T, Asfar T, Rastam S, Maziak W: Are waterpipe smokers interested in quitting? Nicotine \& Tobacco Research 2005, 7(I): I49-156.

33. Frenk Hanan, Dar Reuven : A Critique of Nicotine Addiction Boston: Kluwer Academic Publishers; 2000.

34. Molimard R: Dépendance, la nicotine est-elle la seule responsable? Soins Psychiatr 200I, 2 I4:33-35. [Eng.: Dependence. Is Nicotine solely responsible?]

35. Chaouachi K: E-Letter to the Editor: Serious Errors in this Study. Tobacco Control [http://tc.bmijournals.com/cgi/eletters/|3/4/ 327]. 2004 (2 Dec)

36. Chaouachi K: Post-publication Peer Review : Errors in this New Review. Pediatrics [http://pediatrics.aappublications.org/cgi/ eletters/II6/1/el/3]. 2005 (15 Aug)

37. Chaouachi K: Narghilé: un problema di Sanità Pubblica. Tabaccologia 2006 in press. http://www.tabaccologia.org/archivio.htm [Eng.: Narghile(Hookah) and Public Health]

38. Chaouachi K: Le narguilé. Anthropologie d'un mode d'usage de drogues douces. Paris: Ed. L'Harmattan; 1997. 262 pages. [Eng.: An Anthropology of Narghile: its Use and Soft Drugs]

39. WHO Study Group on Tobacco Product Regulation Guiding principles for the development of tobacco product research and testing capacity and proposed protocols for the initiation of tobacco product testing 2004 [http://www.who.int/tobacco/global interaction/tobreg/en/ index.html]. World Health Organization

40. Final Declaration of the World Congress. In "Health Challenges of the Third Millenium": 2I-26 Aug 2005 Istanbul (Yeditepe University). IFSSH (International Forum for Social Sciences and Health).

4I. Chaouachi K: Letter to the Editor: The Social Context of Individual and Collective Smoking: Similarities and Differences. Tobacco Control [http://tc.bmijournals.com/cgi/eletters/I5/I/59]. 2006 (I Apr)

42. Lee JW: Public health is a social issue. Lancet 2005, 365(9464): $1005-1006$.

Publish with Biomed Central and every scientist can read your work free of charge

"BioMed Central will be the most significant development for disseminating the results of biomedical research in our lifetime. "

Sir Paul Nurse, Cancer Research UK

Your research papers will be:

- available free of charge to the entire biomedical community

- peer reviewed and published immediately upon acceptance

- cited in PubMed and archived on PubMed Central

- yours - you keep the copyright
BioMedcentral 